\title{
ANALISIS STRUKTUR TEKS BACAAN PADA BUKU PELAJARAN “MAHIR BERBAHASA INDONESIA UNTUK SMP/MTS KELAS VII KARANGAN WAHONO, DKK"
}

\author{
Mimi Asti ${ }^{1}$, Agus Trianto ${ }^{2}$, dan M. Arifin ${ }^{3}$ \\ ${ }^{1,2,3}$ Program Studi Pendidikan Bahasa dan Sastra Indonesia \\ Jurusan Pendidikan Bahasa dan Seni \\ FKIP Universitas Bengkulu \\ astimimi@yahoo.com
}

\begin{abstract}
Abstrak
Tujuan penelitian ini untuk memperoleh gambaran mengenai struktur teks bacaan pada buku pelajaran "Mahir Berbahasa Indonesia untuk SMP/MTs Kelas VII" berdasarkan Kurikulum 2013 (revisi 2016). Identitas buku yang dijadikan sebagai objek penelitian ini adalah buku pelajaran bahasa Indonesia kelas VII terbitan Wahono, dkk. Penelitian yang dilakukan menggunakan metode deskriptif dengan menganalisis enam jenis teks bacaan, yaitu teks deskripsi, teks narasi, teks prosedur, teks laporan hasil observasi, teks puisi rakyat, dan teks fabel. Teks yang dianalisis dalam penelitian ini adalah teks yang panjang dan memiliki sumber teks bacaan sebanyak 19 judul teks bacaan. Setiap teks bacaan dianalisis struktur teksnya. Hasil dari penelitian ini menunjukkan bahwa dari 19 judul teks bacaan, dilihat dari unsur kelengkapan, teks yang memiliki struktur yang lengkap sebanyak 12 judul teks bacaan. Teks yang tidak memiliki struktur teks yang lengkap sebanyak 7 judul teks bacaan. Demi menghasilkan buku pelajaran yang berkualitas maka perlu dilakukan penyesuaian struktur teks bacaan pada buku pelajaran, dan juga dalam proses pembelajaran guru harus menyusun buku teks yang baik untuk dibaca siswa.
\end{abstract}

Kata Kunci: Buku teks, pembelajaran berbasis teks, struktur teks.

\begin{abstract}
The purpose of this study is to obtain an overview of the structure of text reading in the textbook "Indonesian Language Proficiency for SMP/MTs Class VII" based on Curriculum 2013 (revision 2016). The identity of the book that serve as the object of this research is the textbook of Indonesian class VII published by Wahono, et al. The research was conducted using descriptive method by analyzing six kinds of text reading, that is description text, narrative text, procedural text, observation report text, people poetry text, and fable text. The texts analyzed in this study are long texts and have a reading text of 19 titles of text. Each text of the text analyzed its text structure. The results of this study show that from 19 titles of text reading, seen from the completeness, text that has a complete structure of 12 titles of text reading. Text that does not have a complete text structure of 7 titles of text reading. In order to produce quality textbooks, it is necessary to adjust the structure of the text text in the textbook, and also in the process of learning the teacher must arrange a good text book for students to read.
\end{abstract}

Keywords: Text book, text-based learning, text structure. 


\section{PENDAHULUAN}

Kurikulum 2013 untuk mata pelajaran bahasa Indonesia menggunakan teks yang harus dikuasai siswa. Oleh sebab itu, mata pelajaran bahasa Indonesia pada Kurikulum 2013 disebut pembelajaran berbasis teks. Priyatni (2014:67) menyatakan bahwa Kurikulum 2013 untuk mata pelajaran bahasa Indonesia menggunakan teks sebagai sarana pembelajaran. Dengan pembelajaran berbasis teks, bahasa Indonesia diajarkan bukan sekadar sebagai pengetahuan bahasa, melainkan sebagai teks yang mempunyai fungsi. Selain itu, dengan adanya pembelajaran berbasis teks dapat menjadikan siswa memahami serta mampu menggunakan teks sesuai dengan tujuan teks yang dipelajarinya.

Menurut Mahsun (2014:95), perancangan pembelajaran bahasa Indonesia berbasis teks memberi ruang pada siswa untuk mengembangkan berbagai jenis struktur berpikir karena setiap teks memiliki struktur berpikir yang berbeda satu sama lain. Karena setiap teks memiliki struktur berpikir yang berbeda, semakin banyak jenis teks yang dikuasai maka semakin banyak struktur berpikir yang dikuasai siswa. Dalam pembelajaran berbasis teks terdapat buku teks yang mengkaji teks sebagai bahan yang dibaca siswa dalam proses pembelajaran.

Menurut Tarigan dan Djago Tarigan (2008:13), buku teks adalah buku pelajaran dalam bidang studi tertentu yang merupakan buku standar, yang disusun oleh para pakar dalam bidang itu buat maksud-maksud dan tujuan instruksional, yang diperlengkapi dengan sarana-sarana pengajaran yang serasi dan mudah dipahami oleh para pemakainya di sekolahsekolah dan perguruan tinggi sehingga dapat menunjang sesuatu program pengajaran. Dengan demikian, buku teks digunakan untuk menunjang suatu pengajaran sehingga dalam melaksanakan pembelajaran di kelas sangat diperlukan buku teks karena dengan buku teks siswa dapat memperoleh berbagai informasi. Selain itu, di dalam buku teks terdapat materi-materi yang disusun secara sistematis sehingga tercipta suasana yang memungkinkan siswa untuk belajar.

Buku teks yang digunakan harus memperhatikan tuntutan kurikulum, artinya suatu buku teks yang akan dikembangkan harus sesuai dengan kurikulum yang sedang digunakan. Apabila buku tersebut sesuai dengan tuntutan kurikulum maka tidak ada hal sulit untuk diperoleh. Karena mata pelajaran bahasa Indonesia dalam Kurikulum 2013 berbasis teks, maka materi di dalam buku teks terdiri atas berbagai jenis teks (bacaan) yang akan dipelajari oleh siswa.

Priyatni (2014:68) menyatakan bahwa dalam buku pelajaran berbasis teks pada jenjang SMP/MTs terdapat 14 jenis teks, yaitu (1) teks hasil observasi, (2) teks tanggapan deskriptif, (3) teks eksposisi, (4) teks eksplanasi, (5) teks cerita pendek, (6) teks cerita moral, (7) teks ulasan, (8) teks diskusi, (9) teks cerita prosedur, (10) teks cerita biografi, (11) teks eksemplum, (12) teks tanggapan kritis, (13) teks tantangan, dan (14) teks rekaman percobaan. Setiap teks bacaan tersebut memiliki struktur teks yang digunakan untuk mengekspresikan pikiran yang dikehendaki dalam setiap struktur teks, dan secara terpadu diorientasikan pada pencapaian tujuan sosial teks secara menyeluruh. Oleh karena itu, setiap teks yang akan dibaca siswa memiliki struktur teks yang dapat menumbuhkan daya pikir siswa terhadap apa yang dibacanya.

Pada buku pelajaran kelas VII terdapat jenis-jenis teks, yaitu teks deskripsi, narasi, prosedur, laporan hasil observasi, puisi rakyat, dan fabel. Dengan dipergunakannya teks sebagai sarana pembelajaran dalam Kurikulum 2013 menyebabkan peran teks dalam 
pembelajaran menjadi hal yang penting. Pemilihan teks dalam pembelajaran dapat menjadi penentu keberhasilan suatu pembelajaran. Untuk itu, teks bacaan tersebut harus dianalisis, misalnya analisis struktur teknya.

Analisis struktur teks digunakan untuk mengetahui apakah teks bacaan sudah memiliki struktur yang lengkap dan menggambarkan susunan bagian-bagian struktur teks dengan jelas kepada siswa atau struktur teksnya tidak tergambar dengan baik dalam suatu teks bacaan. Struktur teks adalah cara teks disusun dan ditata sesuai dengan jenisnya. Sedangkan teks yang lengkap adalah teks yang menggambarkan secara utuh bagianbagian teks sesuai dengan jenisnya. Oleh karena itu, untuk mengetahui hal tersebut perlu dilakukan analisis tentang struktur teks bacaan. Dengan demikian, nantinya akan tergambar teks bacaan tersebut memiliki struktur teks yang lengkap dan menggambarkan bagian-bagian struktur dengan jelas atau struktur teksnya tidak memiliki struktur yang lengkap. Struktur teks yang lengkap dapat membantu suatu proses pembelajaran. Struktur teks bacaan yang tidak lengkap akan berpengaruh ketika siswa diminta untuk menulis karena kebanyakan siswa menulis teks bacaan berdasarkan contoh yang dibacanya. Untuk itu, teks bacaan yang dimuat dalam buku teks harus memiliki struktur teks yang lengkap.

Menurut Tarigan dan Djago Tarigan (2009: 13), buku teks adalah buku pelajaran dalam bidang studi tertentu yang merupakan buku standar, yang disusun oleh para pakar dalam bidang itu buat maksud-maksud dan tujuan instruksional, yang diperlengkapi dengan sarana-sarana pengajaran yang serasi dan mudah dipahami oleh para pemakainya di sekolahsekolah dan perguruan tinggi sehingga dapat menunjang sesuatu program pengajaran.
Hal tersebut sejalan dengan pendapat Hall Quest (dalam Tarigan dan Djago Tarigan 2009:12) yang mengatakan bahwa buku teks adalah rekaman pikiran rasial yang disusun buat maksud-maksud dan tujuan-tujuan instruksional. Bacon (dalam Tarigan dan Djago Tarigan 2009:12) mengatakan buku teks adalah buku yang dirancang buat penggunaan di kelas, dengan cermat disusun dan disiapkan oleh pakar atau para ahli dalam bidang itu dan deperlengkapi dengan sarana- sarana pengajaran yang sesuai dan serasi. Selain itu, Buckingham (dalam Tarigan dan Djago Tarigan 2009:12) mengatakan buku teks adalah sarana belajar yang biasa digunakan di sekolah-sekolah dan perguruan tinggi untuk menunjang suatu program pengajaran dalam pengertian modern dan yang umum dipahami. Menurut Poerwati dan Sofan Amri (2013:217), buku teks adalah suatu tulisan ilmiah dalam bentuk buku yang subtansi pembahasannya fokus pada satu bidang ilmu.

Menurut Tarigan dan Djago Tarigan (2009:19), buku teks memiliki fungsi antara lain; pertama, mencerminkan suatu sudut pandang, kedua, menyediakan suatu sumber yang teratur rapi dan bertahap, ketiga, menyajikan pokok masalah yang kaya dan serasi, keempat, menyediakan aneka metode dan sarana pembelajaran, kelima, menyajikan fiksasi awal bagi tugas dan pelatihan, keenam, menyajikan sumber bahan evaluasi dan remedial.

Berdasarkan uraian di atas, maka penulis merumuskan masalah sebagai berikut: bagaimana struktur teks bacaan pada buku pelajaran "Mahir Berbahasa Indonesia untuk SMP/MTs Kelas VII" Berdasarkan Kurikulum 2013 (Revisi 2016) yang disusun Wahono, dkk?

Tujuan penelitian ini untuk memperoleh gambaran mengenai struktur teks bacaan pada buku pelajaran "Mahir Berbahasa Indonesia untuk SMP/MTs Kelas 
VII" Berdasarkan Kurikulum 2013 (Revisi 2016) yang disusun Wahono, dkk.

\section{METODE}

Penelitian ini menggunakan metode deskriptif karena penelitian ini membahas teks sebagai objek yang akan dianalisis. Dengan demikian, penelitian ini akan mendeskripsikan struktur teks bacaan yang terdapat dalam buku teks kelas VII Kurikulum 2013 mata pelajaran bahasa Indonesia yang disusun oleh Wahono,dkk.

Sumber data penelitian ini adalah buku teks atau buku pelajaran "Mahir Berbahasa Indonesia untuk SMP/MTs Kelas VII" Berdasarkan Kurikulum 2013 (revisi 2016) yang disusun oleh Wahono, dkk. Data penelitian ini merupakan penelitian dokumen. Data yang diambil berasal dari dokumen meliputi teks bacaan yang terdapat pada buku pelajaran bahasa Indonesia kelas VII Kurikulum 2013 yang disusun oleh Wahono, dkk.

Teknik pengumpulan data penelitian ini menggunakan teknik dokumentasi karena pengumpulan data dilakukan dengan membaca buku teks atau buku pelajaran Kurikulum 2013 kelas VII yang disusun oleh Wahono, dkk secara cermat, teliti, dan terarah. Buku teks atau buku pelajaran tersebut akan dianalisis struktur teksnya.

\section{HASIL DAN PEMBAHASAN}

Penelitian ini dilakukan dengan menganalisis teks bacaan pada buku pelajaran "Mahir Berbahasa Indonesia untuk SMP/MTs Kelas VII" berdasarkan Kurikulum 2013 (revisi 2016) yang disusun oleh Wahono, dkk sebanyak enam jenis teks, yaitu teks deskripsi, teks narasi, teks prosedur, teks laporan hasil observasi, teks puisi rakyat, dan teks fabel. Teks bacaan yang memiliki struktur teks pada buku pelajaran tersebut sebanyak 78 judul teks bacaan. Sementara itu, karena keterbatasan yang dimiliki penulis sehingga dalam penelitian ini penulis hanya menganalisis teks bacaan yang panjang dan memiliki sumber teks bacaan yaitu sebanyak 19 judul teks bacaan. Teks bacaan itu akan dianalisis struktur teksnya.

\section{Teks Deskripsi}

Teks deskripsi memiliki struktur teks, yaitu judul, kalimat topik, dan deskripsi. Setelah dilakukan analisis teks deskripsi sebanyak dua judul teks bacaan, yaitu Lingkungan Sekolahku yang Asri, dan Kemegahan Candi Borobudur. Judul kedua teks deskripsi singkat, padat, dan merujuk pada objek yang hendak di deskripsikan. Kalimat topik teks Lingkungan Sekolahku yang Asri dan Kemegahan Candi Borobudur terletak pada paragraf pertama. Akan tetapi, kalimat topik teks Lingkungan Sekolahku yang Asri pada paragraf pertama tidak menggambarkan bagaimana lingkungan sekolah yang asri. Sedangkan kalimat topik teks Kemegahan Candi Borobudur pada paragraf pertama sudah dijelaskan dengan baik dalam teks tersebut. Struktur teks bagian deskripsi teks Lingkungan Sekolahku yang Asri dan Kemegahan Candi Borobudur sudah mendeskripsikan bagian-bagian objek secara rinci.

Dengan tidak adanya struktur teks deskripsi bagian kalimat topik sehingga pada saat membaca teks tersebut pembaca tidak memperoleh penjelasan tentang gambaran umum dari objek yang dideskripsikan. Sedangkan teks yang memiliki struktur yang lengkap dapat membantu dalam proses belajar mengajar. Selain itu, jika teks deskripsi memiliki struktur teks yang lengkap maka ketika siswa membaca teks tersebut siswa seolaholah dapat mendengar, melihat, dan merasakan apa yang dipaparkan. Akan tetapi, jika teks tidak memiliki struktur teks yang lengkap dapat berpengaruh ketika siswa menulis teks karena siswa akan 
menulis teks berdasarkan apa yang dibacanya.

\section{Teks Narasi}

Teks narasi memiliki struktur teks, yaitu judul, pengenalan/orientasi, masalah/komplikasi, dan pemecahan masalah. Setelah dilakukan analisis teks narasi sebanyak dua judul teks bacaan, yaitu: Bayangan dalam Cahaya, dan Pertualangan Mencari Harta Karun. Judul kedua teks narasi sudah mengangkat suatu peristiwa yang akan dipaparkan dalam suatu cerita. Pengenalan/orientasi teks Bayangan dalam Cahaya dan Pertualangan Mencari Harta Karun terletak pada paragraf pertama. Teks Bayangan dalam Cahaya struktur teks narasi bagian pengenalan/orientasi hanya memperkenalkan cerita berupa cerita tentang apa, siapa pelaku dalam cerita, di mana cerita itu terjadi, dan kapan cerita terjadi. Teks tersebut tidak memperkenalkan pelaku/tokoh dalam cerita. Teks Pertualangan Mencari Harta Karun struktur teks bagian pengenalan/orientasi sudah berupa tahap pengenalan cerita karena sudah berisi tahap pengenalan berupa cerita tentang apa, siapa pelaku cerita, di mana cerita terjadi, dan kapan cerita itu terjadi. Teks Bayangan dalam Cahaya dan Pertualangan Mencari Harta Karun sudah menggambarkan struktur teks narasi bagian masalah/komplikasi karena masingmasing teks tersebut sudah menceritakan bagian-bagian tokoh telah mengalami konflik/masalah. Pemecahan masalah teks Bayangan dalam Cahaya dan Pertualangan Mencari Harta Karun sudah digambarkan dengan baik karena masing-masing teks narasi ditutup dengan tahap penyelesaian atau peleraian yang ditutup dengan akhir yang menyenangkan dan menyedihkan. Ketiga teks narasi tersebut ditutup dengan akhir yang menyenangkan.
Dengan tidak adanya struktur teks bagian pengenalan/orientasi maka pada saat membaca paragraf pertama pembaca belum memiliki gambaran yang jelas tentang peristiwa yang terjadi pada tahap pengenalan tersebut. Akan tetapi, jika teks memiliki struktur yang lengkap dapat memudahkan dalam proses belajar mengajar sehingga pada saat siswa diminta untuk menulis teks narasi, siswa akan menulis teks narasi dengan jelas berdasarkan apa yang dibacanya.

\section{Teks Prosedur}

Teks prosedur memiliki struktur teks, yakni: judul, tujuan, bahan atau alat, dan prosedur/tahapan. Setelah dilakukan analisis teks prosedur sebanyak tiga judul teks bacaan, yaitu Cara Memainkan Angklung, Tari Saman, dan Resep Bubur Khas Manado. Judul ketiga teks prosedur sudah berupa cara melakukan/menggunakan sesuatu dan juga sudah berupa nama benda/sesuatu yang hendak dibuat/dilakukan. Tujuan teks Cara Memainkan Angklung dan Tari Saman sudah berupa paragraf pengantar yang menyatakan tujuan penulisan suatu prosedur, yaitu tujuan dari cara memainkan angklung dan tujuan dari melakukan tari saman. Teks Resep Bubur Khas Manado tidak memiliki struktur teks prosedur bagian tujuan karena pada teks tersebut tidak menjelaskan paragraf yang menyatakan tujuan dari resep bubur khas Manado. Struktur teks prosedur bagian bahan atau alat tidak terdapat pada teks Cara Memainkan Angklung dan Tari Saman. Hal itu dikarenakan pada teks prosedur tertentu, misalnya prosedur melakukan sesuatu, tidak memerlukan bahan atau alat. Sedangkan teks Resep Bubur Khas Manado struktur teks prosedur bagian bahan atau alat terletak pada paragraf pertama karena menyatakan daftar/rincian melakukan suatu prosedur, yaitu daftar atau rincian dalam membuat resep bubur 
khas Manado. Selanjutnya, struktur teks prosedur bagian prosedur/tahapan teks Cara Memainkan Angklung, Tari Saman, dan Resep Bubur Khas Manado sudah dijelaskan dengan baik pada masingmasing teks prosedur tersebut yang berupa tahapan/langkah suatu prosedur dibuat atau dilakukan.

Dengan terdapatnya teks prosedur yang tidak lengkap maka ketika siswa membuat suatu prosedur siswa akan kebingungan menjelaskan prosedur tersebut secara urut. Sementara itu, jika teks yang dipaparkan memiliki struktur yang lengkap dapat memberikan petunjuk kepada siswa untuk melakukan atau menggunakan sesuatu dengan langkahlangkah yang urut.

\section{Teks Laporan Hasil Observasi}

Teks laporan hasil observasi memiliki struktur teks, yaitu judul, klasifikasi umum, dan deskripsi. Setelah dilakukan analisis teks sebanyak empat judul teks bacaan, yaitu Rumput, Tanaman Lamtoro, Kedelai, dan Jati. Judul keempat teks laporan hasil observasi sudah memunculkan ciri khas dari sesuatu yang hendak di informasikan. Klasifikasi umum teks Rumput, Tanaman Lamtoro, Kedelai, dan Jati sudah berisi fenomena benda yang akan dibicarakan yang menyertakan pernyataan umum dari objek yang diamati atau dibicarakan tersebut. Selanjutnya, struktur teks laporan hasil observasi bagian deskripsi teks Rumput, Tanaman Lamtoro, dan Jati tidak menggambarkan bagian objek yang diamati atau dibicarakan secara rinci karena ada bagian-bagian objek yang tidak dijelaskan pada teks tersebut. Sedangkan teks Kedelai sudah memiliki struktur teks laporan hasil observasi bagian deskripsi dengan baik karena teks tersebut sudah menjelaskan bagian-bagian kedelai secara rinci sehingga pada saat membaca teks tersebut pembaca mempunyai gambaran yang jelas dari objek yang dipaparkan tersebut.

Teks yang memiliki struktur teks yang lengkap dapat membantu dalam proses belajar mengajar sehingga siswa dapat menulis teks laporan hasil observasi dari objek yang diamatinya secara jelas dan rinci. Akan tetapi, jika teks yang dipaparkan tidak memilki struktur yang lengkap akan berpengaruh kepada siswa pada saat mereka akan menulis teks tersebut. Hal itu dikarenakan kebanyakan siswa menulis teks berdasarkan contoh teks yang dibacanya.

\section{Teks Puisi Rakyat}

Setelah dilakukan analisis teks sebanyak empat judul teks bacaan, yakni: teks syair (teks 1), teks syair (teks 2), teks syair (teks 3), dan teks syair (teks 4). Teks syair memiliki struktur teks, yakni: sampiran dan isi. Keempat teks syair sudah menjelaskan struktur teks dengan baik, yaitu sampiran dan isi. Sampiran dan isi masing-masing teks syair terdiri 4 baris, bersajak aaaa, dan setiap barisnya terdiri atas 4-6 kata dengan 10-13 suku kata. Teks yang memiliki struktur teks yang lengkap dapat membantu dalam proses pembelajaran. Sedangkan jika teks syair tidak memiliki struktur yang lengkap dapat berpengaruh ketika siswa diminta untuk menulis teks syair karena siswa juga akan menulis teks berdasarkan contoh teks yang dipaparkan.

\section{Teks Fabel}

Teks fabel memiliki struktur teks, yaitu judul, pengenalan/orientasi, masalah/komplikasi, dan pemecahan masalah/resolusi. Setelah dilakukan analisis teks sebanyak empat judul teks bacaan, yaitu Kisah Semut dan Kepompong, Kucing dan Beruang, KuraKura dan Monyet yang Rakus, dan Kancil dan Kura-Kura. Judul teks keempat teks fabel tersebut sudah mengangkat suatu 
topik yang akan diceritakan. Pengenalan/orientasi teks Kisah Semut dan Kepompong, Kucing dan Beruang, KuraKura dan Monyet yang Rakus, dan Kancil dan Kura-Kura terletak pada paragraf pertama. Pada teks Kisah Semut dan Kepompong, Kura-Kura dan Monyet yang Rakus, dan Kancil dan Kura-Kura struktur teks fabel bagian pengenalan/orientasi sudah tergambar dengan baik dalam teks tersebut karena sudah berupa paragraf yang menyertakan pendahuluan cerita yang memperkenalkan tokoh-tokoh dan tempat terjadinya cerita. Teks Kucing dan Beruang, struktur teks fabel bagian pengenalan/orientasi tidak menggambarkan struktur teks fabel yang baik karena pada paragraf pertama tidak memperkenalkan tempat terjadinya cerita melainkan hanya memperkenalkan tokohtokoh dalam cerita. Masalah/komplikasi teks Kisah Semut dan Kepompong, Kucing dan Beruang, Kura-Kura dan Monyet yang Rakus, dan Kancil dan Kura-Kura sudah berupa paragraf yang memperkenalkan masalah hingga terjadi konflik atau klimaks cerita. Pemecahan masalah/resolusi keempat teks fabel sudah tergambar dalam cerita. Hal itu dikarenakan masing-masing teks fabel tersebut ditutup dengan tahap penyelesaian dengan akhir yang menyenangkan dan menyedihkan. Teks Kisah Semut dan Kepompong, Kancil dan Kura-Kura struktur teks fabel bagian penyelesaian masalah/resolusi ditutup dengan akhir yang menyenangkan. Sedangkan teks Kucing dan Beruang, KuraKura dan Monyet yang Rakus tahap penyelesaian ditutup dengan akhir yang menyedihkan.

Dengan terdapatnya struktur teks fabel bagian pengenalan/orientasi yang tidak lengkap maka pada saat membaca paragraf pertama pembaca belum memiliki gambaran yang jelas tentang pendahuluan suatu cerita. Akan tetapi, jika teks memiliki struktur yang lengkap dan menggambarkan bagian-bagian struktur teks dengan jelas dapat memudahkan siswa dalam menulis teks dan siswa dapat memahami dengan jelas pesan moral yang terdapat pada teks fabel.

\section{PENUTUP \\ Kesimpulan}

Berdasarkan hasil penelitian dan pembahasan dapat disimpulkan bahwa dari 19 judul teks bacaan terdapat 12 judul teks bacaan yang memiliki struktur teks yang lengkap, dan 7 judul teks bacaan yang tidak memiliki struktur teks yang lengkap.

Teks bacaan yang memiliki struktur teks yang lengkap yaitu teks Kemegahan Candi Borobudur, Teks Pertualangan Mencari Harta Karun, Teks Cara Memainkan Angklung, Teks Tari Saman, Teks Kedelai, Teks Syair (Teks 1), Teks Syair (Teks 2), Teks Syair (Teks 3), Teks Syair (Teks 4), Teks Kisah Semut dan Kepompong, Teks Kura-Kura dan Monyet yang Rakus, Teks Kancil dan Kura-Kura. Teks yang tidak memiliki struktur teks yang lengkap yaitu Teks Lingkungan Sekolahku yang Asri, Teks Bayangan dalam Cahaya, Teks Resep Bubur Khas Manado, Teks Rumput, Teks Tanaman Lamtoro, Teks Jati, dan Teks Kucing dan Beruang.

\section{Saran}

1. Dalam proses pembelajaran guru harus memodifikasi/menyusun buku teks yang baik untuk siswa.

2. Perlu adanya penyesuaian struktur teks yang terdapat dalam buku pelajaran tersebut. Hal itu dilakukan agar teks bacaan memiliki struktur teks yang lengkap untuk dibaca oleh siswa.

3. Dalam penyusunan buku-buku pelajaran bahasa Indonesia khususnya pada Kurikulum 2013 yang berbasis teks perlu dilakukan analisis struktur teksnya terlebih dahulu agar buku yang dikeluarkan benar-benar memiliki 
struktur yang lengkap untuk dibaca siswa.

4. Perlu adanya penelitian lain mengenai analisis struktur teks bacaan buku pelajaran bahasa Indonesia Kurikulum 2013.

\section{DAFTAR PUSTAKA}

Mahsun. 2014. Teks dalam Pembelajaran Bahasa Indonesia Kurikulum 2013. Jakarta: PT Raja Grafindo Persada.

Poerwati, Loeloek Endah dan Sofan Amri. 2013. Panduan Memahami Kurikulum 2013. Jakarta: PT Prestasi Pustakaraya.
Priyatni, Endah Tri. 2014. Desain Pembelajaran Bahasa Indonesia dalam Kurikulum 2013. Jakarta: PT Bumi Aksara.

Tarigan, Henry Guntur dan Djago Tarigan. 2009. Telaah Buku Teks Bahasa slndonesia. Bandung: Penerbit Angkasa.

Wahono, dkk. 2016. Mahir Berbahasa Indonesia untuk SMP/MTs Kelas VII. Jakarta: Erlangga. 